\title{
Review of Some Effects of Climate Change on Indoor Environmental Quality and Health and Associated No-Regrets Mitigation Measures
}

\author{
William J. Fisk* \\ Indoor Environment Group, \\ Lawrence Berkeley National Laboratory \\ 90R3058, 1 Cyclotron Rd \\ Berkeley, CA
}

*corresponding author

wjfisk@lbl.gov

Tel. 5104865910 


\section{ABSTRACT}

This paper reviews the potential health consequences of changes in climate that affect indoor environments, with an emphasis on residential environments in the U.S. and Europe. These changes in climate, include increases in the frequency and severity of heat waves, severe storms coupled with sea level rise, and wildfires, plus increases in urban airborne ozone. The potential for adverse health effects is substantial. Examples of projected effects include a doubling of heat-related deaths, increased hospitalizations for asthma, pneumonia, and cardiovascular effects during wildfires, and increased mortality and hospitalizations associated with ozone. The associated adverse exposures occur, to a significant extent, indoors. The adverse health effects will be substantially mediated by features of buildings, particularly of homes where people, particularly those most susceptible, spend the largest amount of time. Changes to buildings, or to building operations, are identified that could reduce the projected adverse health effects of climate change. Examples include improved roof insulation, roof coatings that reflect more solar energy, and more air conditioning to reduce indoor overheating. Improved particle filtration systems could reduce the health effects of particles from wildfires. Some of these measures will also reduce building energy use and the associated emissions of greenhouse gases. Most of these measures would improve health irrespective of climate change. Improvements in building energy efficiency in order to mitigate climate change, has to potential to either improve or worsen indoor environmental quality and health.

\section{Keywords: building, climate change, health, indoor air quality, indoor environmental quality,} mitigation

\subsection{INTRODUCTION}

Figure 1, adapted from [1], shows selected pathways through which climate change (CC) is likely to modify indoor environmental quality (IEQ). These pathways fit within three broad categories: 1) outdoor environmental changes that, in turn, influence IEQ; 2) CC adaptation measures, i.e., measures taken in response to changes in climate, that affect IEQ; and 3) changes in buildings to mitigate, i.e., reduce, the extent of climate change. The first category includes: increases in heat waves, severe storms coupled with sea level rise, and wildfires; increased outdoor ozone in urban areas; and increases in outdoor pollens. The second category includes increased use of air conditioning and the third category includes increased building energy efficiency. IEQ conditions, comfort conditions, and health may be affected positively or negatively, depending on the change in climate, and on the CC mitigation and adaptation measures implemented. Ideally, in the selection of CC mitigation and adaptation measures, priority would be placed on measures that also improve IEQ and comfort or health.

The most comprehensive prior review of the linkages of CC with IEQ was performed by a committee of the Institute of Medicine (IOM) [1], and was also briefly summarized by [2]. The IOM report provides an excellent summary of the state of knowledge in the IEQ field and was the starting point for the organizational framework in Figure 1. The IOM concluded that there was little information available that directly addresses the intersection of CC, IEQ, and health. Consequently, the IOM reviewed relevant information on each of the intersecting topics and developed findings based on a synthesis. Key findings included:

"There is inadequate evidence to determine whether an association exists between climate-changeinduced alterations in the indoor environment and any specific adverse health outcomes. However 
available research indicates that CC may make existing indoor environmental problems [worse] and introduce new problems by:

- Altering the frequency or severity of adverse outdoor conditions that affect the indoor environment.

- Creating outdoor conditions that are more hospital to pests, infections agents, and disease vectors that can penetrate the indoor environment.

- Leading to mitigation and adaption measures and changes in occupant behavior that cause or exacerbate harmful indoor environmental conditions".

The IOM report then summarized related literature pertaining to: air quality; dampness, moisture, and flooding; infectious agents and pests; thermal stress; building ventilation, weatherization, and energy use. The IOM report relied on literature available before or during 2010 and placed little emphasis on the identification of mitigation measures for reducing adverse indoor-environmental health effects anticipated to result from CC.

A subsequent paper by one of members of the IOM committee provided a general review of the potential consequences of $\mathrm{CC}$ for indoor exposures to volatile and semi-volatile organic and inorganic gaseous pollutants as well as particles [3]. The paper focuses on the "factors that influence the indoor concentrations of health relevant pollutants and how concentrations might shift as a consequence of $\mathrm{CC}^{\prime \prime}$. Accordingly, this paper summarizes basic knowledge needed to develop an understanding of how CC may affect exposures to gaseous and particulate pollutants.

Since the IOM report [1] was published, substantial new relevant literature has been published and the Intergovernmental Panel on Climate Change (IPCC) has also released a new report on how CC is expected to affect climate and human health [4]. The purpose of the current paper is to provide an updated and more in-depth assessment pertaining to how CC may affect IEQ-related health risks related to heat waves, wild fires, ozone, severe storms and flooding, and building energy efficiency. In addition, the purpose included assessment of linkages between changes in outdoor environmental conditions and associated indoor environmental conditions and identification of related mitigation measures.

The effects of CC on IEQ and health are expected to vary regionally and among segments of the population. The elderly, people with poor health, and the economically disadvantaged may be most affected. While many of the issues addressed in this review are relevant throughout the world, most current literature pertains to the effects of $\mathrm{CC}$ in the more developed sections of the world, especially North America and Western Europe; thus, this review has the same overall bias.

The review only considers potential IEQ-related health effects associated with heat waves, wild fires, severe storms and flooding, and ozone, plus an assessment of some of the key effects of improved building energy efficiency in homes as a means of CC mitigation. Not addressed are: effects of climaterelated changes in indoor exposures of pollens, outdoor particles (except from wildfires), and vectors; and effects of increased use of air conditioning and other likely adaptations to CC. There are also many anticipated effects of CC on health that are unrelated to IEQ that are not discussed. Changes in IEQ attributable to CC may occur simultaneously with other changes that also affect IEQ but are not attributable to CC. For example, at the same time that changes in climate affect outdoor and indoor ozone levels, the implementation of outdoor air quality control measures, such as measures that reduce pollutant emissions from vehicles, and population growth will also modify outdoor and associated indoor ozone levels in many cities. To the degree possible, this review addresses the isolated effects of CC. 


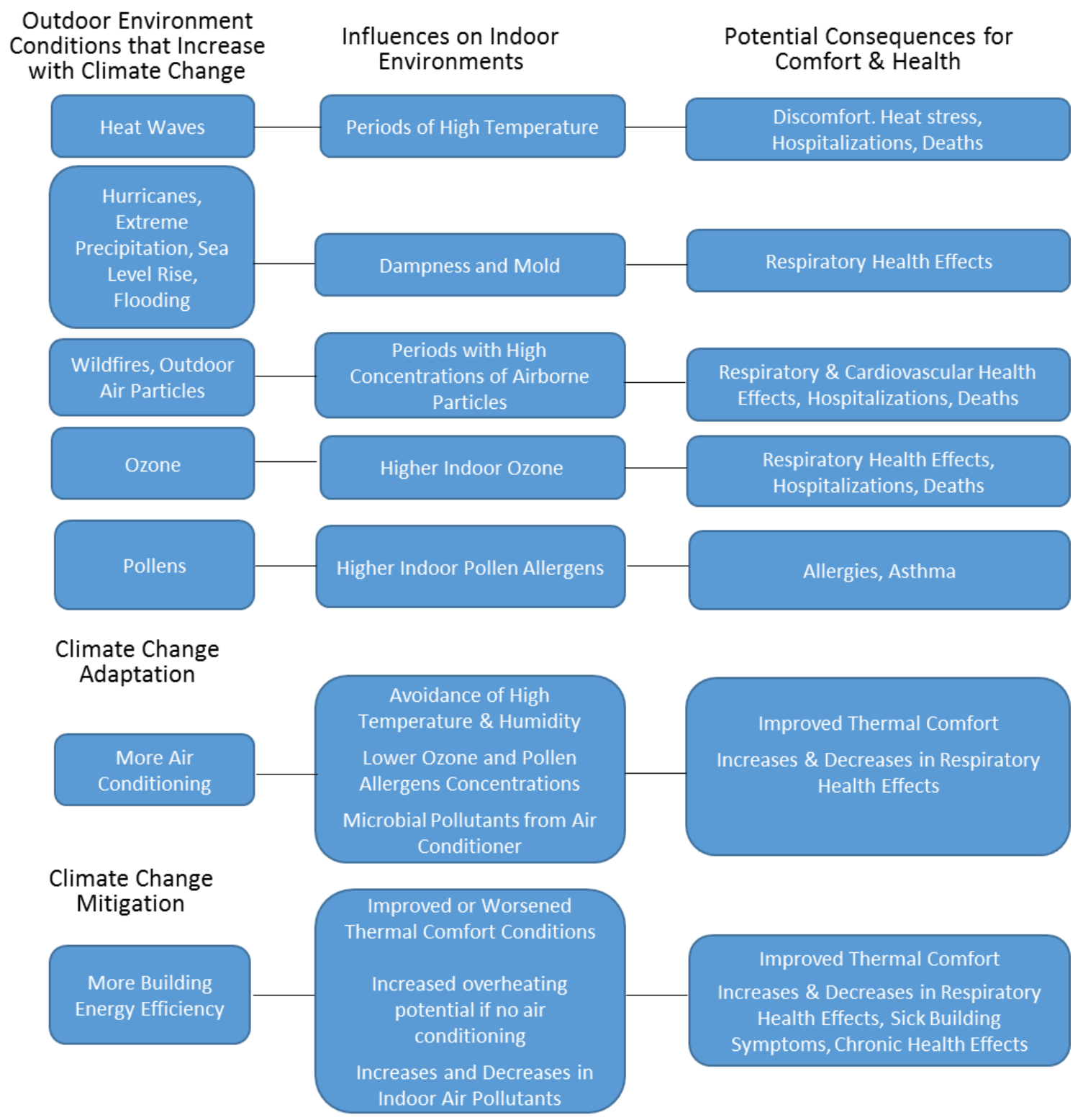

Figure 1. Examples of how CC may affect indoor environments and health (adapted from [1])

\subsection{METHODS}

Data are not available that directly indicate how CC affects IEQ and IEQ-related health effects.

Consequently, it was necessary to combine information from multiple fields, and apply knowledge of how building and outdoor environmental factors affect IEQ, to project how CC will influence IEQ and IEQ-related health. Published information in the following general areas was employed:

1. Predictions of how CC will affect outdoor weather conditions, outdoor air pollution, sea level, and wildfires.

2. Predictions of how CC will affect health outcomes, when the associated exposures occur partly when people are indoors. 
3. Published information relating health outcomes to heat waves, outdoor ozone, building dampness and mold.

4. Published information relating indoor environmental conditions to outdoor environmental conditions and building characteristics.

Reports from the IPCC, including those released subsequent to the IOM's review were an important source of information in areas 1 - 3. In addition, papers published in refereed archival journals and from governmental organizations were identified using the Web of Science, Google Scholar, and Pub Med search engines. Searches employed various combinations of the following terms: CC, heat waves, wild fires, ozone, buildings, homes, indoor air quality, indoor environmental quality, dampness and mold, health, asthma, respiratory, symptoms, hospitalization, premature death, morbidity, mortality, thermal stress, heat stress. Reference lists of papers identified in initial searches were a source of additional papers. Also, the names of authors of useful papers prompted searches for other papers by the same authors. Relative to area 4, additional searches identified papers relating indoor to outdoor particles and indoor to outdoor ozone using search terms listed above plus: indoor, outdoor, relationship, ratio, filtration, particle.

Abstracts were reviewed and full papers were reviewed when applicable. When substantial numbers of papers were available in a subject area, key summary information was compiled in tables. Findings reported in this paper were generally qualitative judgments reflecting the number of studies published, study quality and uncertainty, and consistency of results

\subsection{RESULTS}

\subsection{Thermal Stress and Deaths during Heat Waves}

Longer and more severe heat waves are expected as the climate warms [5-7] . For example, Wu, Zhou [6] project that the average annual number of heat waves in the Eastern U.S. will increase by approximately a factor of five from 2002-2004 to 2057-2059, and that the average heat wave in 20572059 will be one day longer than the average heat wave in 2002-2004. The California Environmental Protection Agency projects more than a doubling of extreme heat days between 2050 and 2099 in most California cities [8]. Based on historical data, heat waves are associated with increased adverse health effects including hospital admissions and premature deaths. Tens of thousands of premature deaths have been linked to heat waves in 2003 in Europe and in 2010 in Russia [8, 9].

The IPCC summarized five projections of how CC will affect annual heat and cold mortality, and the projected effects on mortality vary among countries [10].

- Annual increases in heat-related mortality in the United Kingdom for the period up to 2080 is projected to be smaller than annual decreases in cold-related mortality.

- In Germany, a $20 \%$ increase in heat-related mortality by 2055 is not compensated by a reduction in cold related mortality.

- For Portugal a several-fold increase in heat-related mortality is predicted by 2050 and 2080.

- Annual heat-related deaths in Los Angeles are projected to increase from 165 in the 1990 s to between 320 and 1200 in 2080.

- For Australian capital cities, annual heat-related deaths are projected to increase from 82 per 100,000 in 2003 to 250 per 100,000 in 2100. 
The first projection in the list above is that decreases in winter mortality in the United Kingdom will exceed the increases in heat-related deaths. A more recent study challenges this finding, at least for England and Wales [11]. With improvements in housing quality, standard of living, and increased assistance to vulnerable populations, cold winter weather after 1976 was no longer significantly associated with mortality. The most recent review of health effects of CC by the IPCC states that worldwide the increases in heat stress deaths will outweigh the reductions in cold related deaths [12]. An analysis for the U.S. comes to the same conclusion [7]. Also, Ebi and Mills [13] evaluated the relationship of cold temperatures with mortality and the underlying causes of the association and conclude that CC will also not "dramatically reduce winter mortality rates". The final three projections in the prior list range from a $20 \%$ increase in heat -related mortality to as much as a seven-fold increase in mortality. The differences in geographic locations and climates, population susceptibility, and assumptions about the extent of climate change contribute to the variability in the projections.

Huang, Barnett [14] reviewed 14 papers that predict changes in heat-related deaths as a result of CC, and most studies project between a doubling and a several-fold increase in associated mortality. Deaths associated with cold temperatures during the winter were projected to diminish, but by far less than increases in deaths from heat waves.

$\mathrm{Wu}, \mathrm{Zhou}[6]$ estimate that the increased frequency of heat waves may cause heat-wave deaths in the Eastern U.S. to increase 10 fold by 2057-2059. Heat wave deaths were projected to increase by between 1400 and 3600 per year by 2058. The large range in projected increases in mortality is a consequence of different estimates of risks of death during heat waves, magnitudes of climate warming, and different definitions of heat waves.

Heat waves affect the elderly markedly more than younger people. An analysis of heat-wave-related deaths in Europe for the 1990 to 2002, and 2004 period found that during heat waves, the rate of all natural deaths for age greater than 65 increased from 7.6\% in Munich to 33.6\% in Milan [15]. Percentage increases in deaths during heat waves increased markedly with age in the all cause, respiratory, cardiovascular, and cerebrovascular death categories. From analysis of the 2006 heat wave in France, $61 \%$ of excess deaths were for age greater than 75 and $80 \%$ of excess deaths were for age greater than 55 [16]. In the 2003 heat wave in France, about 54\% of deaths occurred in people located at home or in retirement homes, and the percentage increase in deaths was higher for people at home than for people in hospitals and clinics [17].

Additional studies indicate that the elderly, young children, people with poor health, the poor who live in substandard housing and cannot afford air conditioning, and people living in urban centers are more highly susceptible to heat stress [8, 18-20]. The National Human Activity Pattern Survey in the U.S., indicates that people age 65 and older spend $81 \%$ of their time indoors at home [21] and a study of elderly subjects with coronary heart disease in Amsterdam, the Netherlands, and Helsinki Finland found that $88 \%$ of time was spent indoors at home [22]. These findings suggest that many and perhaps most heat wave deaths occur in the elderly population generally located indoors, and often at home, as opposed to among people working outdoors. Thus, high indoor temperatures during periods of high outdoor air temperature are indicated as a key cause of death during heat waves. Blackouts (electrical power outages) from overtaxed electrical systems during heat waves, from severe storms, or simply coincidental with heat waves could increase the adverse health effects. Living on the top floor of a building, poor thermal insulation, and lack of air conditioning increase the risk of death in a heat wave $[20,23]$. Some of the risk factors for heat-related illness or death, such as lack of air conditioning, may 
be increased in locations that have not typically had frequent heat waves, increasing peoples' susceptibility at these locations.

Given the ages and health conditions of the most susceptible people, priority should be placed on mitigation measures applicable to homes, rather than work places. Addition of air conditioning, improvements in thermal insulation of attics, cool roofing coatings that adsorb less solar radiation, external shading, and improved windows to reduce heat gain from outdoors, as well as education, better warning systems, and a range in public health measures during heat waves could diminish future adverse health effects [24-31]. Some of these measures, such as cool roof coatings and external shading may increase the need for heating in the winter or slightly reduce winter comfort conditions, so full year effects should be assessed. Addition of interior wall insulation can sometimes increase indoor overheating $[27,30,32]$ because of the decreased thermal mass in contact with indoor air and decreased rate of cooling of the home at night. Of these measures, thermal insulation, cool roofing, external shading, and improved windows will usually save energy and help to reduce the emissions of carbon dioxide that contribute to CC. These measures, except possibly internal wall insulation, will improve indoor thermal comfort conditions and reduce health effects of heat stress irrespective of CC. These same measures will also provide some protection from heat waves during power outages when air conditioning is not available. Our ability to evaluate and select among mitigation options is, however, presently hampered by the lack of widely accepted indoor heat thresholds pertaining to protection of human health [33].

\subsection{Dampness and Mold from Severe Storms and Sea Level Rise}

According to Intergovernmental Panel on CC (IPCC), current data indicate likely increases in the frequency, intensity and amount of heavy precipitation since 1950, and further increases in the $21^{\text {st }}$ century are very likely [34]. Increases in tropical cyclones are likely by the end of the $21^{\text {st }}$ century [34] and the severity of cyclones has increased during the past 20 years [35]. Also, the IPCC and other reviews indicate that sea level is rising, and rising more rapidly over time [7, 34, 35]. By the end of the $21^{\text {st }}$ century, the global average sea level is expected to increase by 0.26 to $0.82 \mathrm{~m} \mathrm{[34].}$

Increases in heavy precipitation events, particularly when coupled with high winds as in cyclones or hurricanes, are expected to increase water entry into buildings through failures of the envelope, and via flooding. Flooding is expected to increase in much of the U.S. [7]. Sea level rise coupled with storm surges will increase coastal flooding [36-38]. Coastal flooding events projected to occur once per century are projected to occur once per decade by 2050 at one third of the 55 coastal U.S. locations considered by Tebaldi, Strauss [38], increasing the frequency of flooding of coastal buildings.

Water damage and flooding of buildings are linked to increases in microbial agent (mold and bacteria) growth on building surfaces [39], and dampness and mold problems in buildings are associated with substantial increases in adverse respiratory health symptoms, including asthma symptoms [39-41]. Increased dampness and mold in buildings may also lead to increased respiratory infections [42].

Together, this evidence suggests that $\mathrm{CC}$ will lead to significant increases in adverse health effects associated with building dampness and mold unless actions are taken to make buildings less susceptible to extreme precipitation events and flooding. While current information is insufficient for predicting the magnitude of changes in adverse health effects, even moderate increases in dampness and mold in buildings would be of concern. For example, one can estimate health effects and costs if CC caused a $25 \%$ increase in dampness and mold in U.S. buildings. 
- Based on a meta-analysis of a substantial body of literature, Mudarri and Fisk [43] estimated that 4.6 (range $2.7-6.3$ ) million cases of current asthma were attributable to dampness and mold in U.S. homes in 2004 , with an annual cost of $\$ 4.5$ (range $\$ 2.1-\$ 4.8$ ) billion. A $25 \%$ increase corresponds to 1.2 million additional cases of current asthma, with an annual cost of approximately $\$ 1$ billion.

- Based on another meta-analysis [42], between $8 \%$ and $20 \%$ of several common respiratory infections, such as common cold and acute bronchitis, are attributable to dampness and mold in homes. A $25 \%$ increase in dampness and mold corresponds to a $2 \%$ to $5 \%$ increase in common respiratory infections.

- Fisk, Black [44], estimated that a $30 \%$ decrease in dampness and mold in U.S. offices may annually prevent 1.5 million days of sick leave and with an annual economic value of $\$ 0.5$ billion. This estimate has considerable uncertainty because of the limited supporting data [45]. However, the implication is that a $25 \%$ increase in dampness and mold in U.S. offices caused by CC would lead to approximately 0.4 million additional days of sick leave in U.S. office workers per year, with an economic effect of $\$ 125$ million.

Potential mitigation measures include changes in building envelope design and construction practices to reduce the potential for water entry [39, 46-48]. Improved maintenance of building envelopes can also reduce dampness problems, for example replacing roofs before they leak and fixing leaks quickly after they are detected. Also, elevating buildings above grade level (e.g., supporting buildings on raised piers) in flood-prone locations and locating fewer buildings in flood plains, can reduce the extent to which CC increases dampness and mold in buildings. Construction of sea walls could reduce coastal flooding during storm surges. Mold resistant wall board materials and use of foam insulation materials that hold less water than traditional insulations may also reduce risks; however, insufficient data are available on their effectiveness. Many of these actions make good sense, irrespective of CC, as building dampness and mold in the current climate are a significant source of adverse health effects and impose high costs for building repairs and mold remediation.

\subsection{Wildfires}

Increased outdoor temperatures and heat waves are expected to lead to increased wildfires. Data suggest a large increase since 1983 in area burned per year in the U.S. [35], although the large year-toyear variability make conclusions difficult. Climate change is also projected to increase the number and severity of droughts in some regions of the world, also contributing to increased wildfires. Spracklen, Mickley [49] have estimated that, by 2050 , CC will cause a $54 \%$ increase in the average area burned in the western U.S.

While the effects of CC on time average concentrations of outdoor particle are highly uncertain [7, 50, 51], wildfires can cause temporary large increases in outdoor airborne particles, and substantial increases in gaseous air pollutants such as carbon monoxide, nitrogen dioxide, formaldehyde, and acetaldehyde [52-55]. Large wildfires can increase air pollution over thousands of square kilometers [10, $53,56]$. Calculations based on model projections [49] indicate that CC-driven wildfires and changes in outdoor particle transport will increase summertime mean outdoor-air levels of fine particles in the western U.S. by $30 \%$ to $40 \%$. Percentage increases in fine particles in urban areas that have higher current particle concentrations are likely to be smaller. Analyses of particle data indicate a several-fold increase in outdoor airborne particles during a wild fire that occurred in Southern California in 2003 [53]. Researchers found that population-weighted concentrations of particles less than $2.5 \mu \mathrm{m}$ in diameter (PM2.5) were $90 \mathrm{\mu g} \mathrm{m}^{-3}$ under heavy smoke conditions and $75 \mu \mathrm{g} \mathrm{m}^{-3}$ under light smoke conditions, which compare to $20 \mathrm{\mu g} \mathrm{m}^{-3}$ during the non-fire periods. For particles less than $10 \mu \mathrm{m}$ in diameter 
(PM10), population-weighted concentrations were $190 \mu \mathrm{g} \mathrm{m}^{-3}$ under heavy smoke conditions and $125 \mu \mathrm{g}$ $\mathrm{m}^{-3}$ under light smoke conditions, which compare to $40 \mu \mathrm{g} \mathrm{m}^{-3}$ during the non-fire periods.

During an extreme long-term fire in Indonesia, highly affected areas had more than $1000 \mu \mathrm{g} \mathrm{m}^{-3}$ of PM10 for several days and long periods with more than $150 \mathrm{\mu g} \mathrm{m}^{-3}$ [57]. Concentrations of PM10 as high as $1860 \mu \mathrm{g} \mathrm{m}^{-3}$ were reported [58]. U.S. EPA National Ambient Air Quality Standards specify that concentrations of PM10 particle pollution should not exceed $150 \mathrm{\mu g} \mathrm{m}^{-3}$, on average, more than once per year [59].

Several, but not all, studies have documented increases in adverse health effects in populations exposed to pollutants from wildfires. Health effects assessed in these studies have included hospital admissions for various causes, mortality, respiratory symptoms (such as cough and wheeze), eye and nose symptoms, and respiratory infections (colds, bronchitis, and pneumonia) $[52,54,56,57,60]$. The elderly, infants, and those with preexisting respiratory diseases such as asthma and chronic obstructive pulmonary disease may be most susceptible. In general, the studies have compared the prevalence of adverse health effects in a defined population during periods with and without exposures to pollutants from wildfires. The concentrations of air pollutants in populations exposed to wildfires, and the periods of time over which pollutant concentrations are elevated, vary widely among wildfire events. Also, the baseline level of health and access to health care of exposed populations vary widely. Consequently, one would not expect different studies to detect the same size increase in adverse health effects.

Table 1 summarizes several studies of the health effects of pollution from wildfires. The first study of a Southern California population reports several statistically significant increases in in hospital admissions related to respiratory health effects, ranging from $3 \%$ to $10 \%$ per each $10 \mu \mathrm{g} \mathrm{m}^{-3}$ increase in ambient PM2.5. The second study of high school students during the same wildfire event reported increases in irritation and respiratory symptoms, medication use, and doctor visits that usually were between $30 \%$ and $300 \%$. In most cases the increases were statistically significant. The third study, of two communities in British Columbia, reports statistically significant $46 \%$ to $78 \%$ increases in visits to physicians for respiratory health effects in the more highly affected community, but no statistically significant increases in the second community. The fourth study found no statistically significant increase in mortality in Denver associated with short-term exposures to pollutants from wildfires. The last two studies address the health effects of a very large multiple-month wildfire in Indonesia. A study of an affected Malaysian community reports a statistically significant $70 \%$ increase in non-traumatic deaths among residents with an age of 64 to 74 , and a non-significant $19 \%$ increase for all ages. The final study analyzed census data and suggested that wildfire pollution is responsible for 15,600 child, infant, and fetal deaths, indicating a 1.2\% decrease in survival of those born or expected to be born during the period of exposure to pollutants from the wildfire.

Table 1. Reported health effects of wildfires.

\begin{tabular}{|c|c|c|c|c|}
\hline $\begin{array}{l}\text { Refer- } \\
\text { ence }\end{array}$ & $\begin{array}{c}\text { Study } \\
\text { Population }\end{array}$ & $\begin{array}{l}\text { Particle Levels } \\
\qquad \mathrm{g} \mathrm{m}^{-3}\end{array}$ & $\begin{array}{l}\text { Duration } \\
\text { of } \\
\text { Exposure }\end{array}$ & $\begin{array}{l}\text { Increases in Health Effects } \\
\text { (bold if statistically significant) }\end{array}$ \\
\hline [52] & $\begin{array}{l}\text { Residents of five } \\
\text { Southern } \\
\text { California } \\
\text { counties }\end{array}$ & $\begin{array}{l}\text { PM2.5 increases } \\
\text { compared to non- } \\
\text { fire periods : } \\
55 \text { (light smoke } \\
\text { areas) } \\
70 \text { (heavy smoke } \\
\text { areas) }\end{array}$ & 1.5 month & 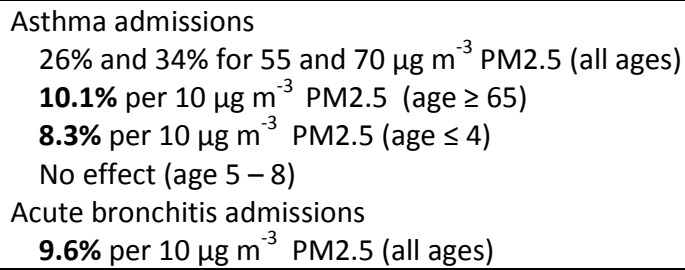 \\
\hline
\end{tabular}




\begin{tabular}{|c|c|c|c|c|}
\hline & & $\begin{array}{l}240 \text { (peak 24-h } \\
\text { average) }\end{array}$ & & $\begin{array}{l}\text { COPD* admissions } \\
\text { 6.8\% per } 10 \mu \mathrm{g} \mathrm{m}^{-3} \mathrm{PM} 2.5 \text { (age } 20-64 \text { ) } \\
\text { Pneumonia admissions } \\
\mathbf{2 . 8 \%} \text { per } 10 \mu \mathrm{g} \mathrm{m}^{-3} \mathrm{PM} 2.5 \text { (all ages) } \\
\text { Cardiovascular admissions (all ages) } \\
\text { No significant effects per } 10 \mu \mathrm{g} \mathrm{m}^{-3} \text { PM2.5 (all ages) }\end{array}$ \\
\hline [54] & $\begin{array}{l}873 \text { high school } \\
\text { students and } \\
5551 \\
\text { elementary } \\
\text { grade students } \\
\text { from } 16 \text { towns } \\
\text { in Southern } \\
\text { California }\end{array}$ & $\begin{array}{l}\text { PM10 Five-day } \\
\text { mean levels in } 16 \\
\text { towns ranged from } \\
30 \text { to } 252\end{array}$ & $\begin{array}{l}\sim 1.5 \\
\text { month }\end{array}$ & $\begin{array}{l}\text { Eye, nose and throat symptoms, cough, bronchitis, } \\
\text { cold, wheezing, asthma attacks, medication use, and } \\
\text { physician visits increased generally by } 30 \% \text { to } 300 \% \\
\text { most increases are statistically significant }\end{array}$ \\
\hline$[61]$ & $\begin{array}{l}\text { Kelowna and } \\
\text { Kamloops } \\
\text { communities in } \\
\text { British Columbia }\end{array}$ & $\begin{array}{l}\text { PM2.5 Peaks: } \\
200 \text { in Kelowna } \\
140 \text { in Kamloops }\end{array}$ & five weeks & $\begin{array}{c}\text { In Kelowna } 46 \% \text { to } 78 \% \text { increase in physician visits for } \\
\text { respiratory diseases (statistically significant during } 3 \\
\text { weeks) } \\
\text { In Kamloops no statistically significant increases in } \\
\text { physician visits }\end{array}$ \\
\hline$[60]$ & $\begin{array}{l}\text { Residents of } \\
\text { Denver } \\
\text { metropolitan } \\
\text { area }\end{array}$ & $\begin{array}{l}\text { PM2.5 Peaks of } 200 \\
\text { for } 4-5 \text { hours on } \\
\text { each of two days }\end{array}$ & two days & no clear statistically significant increases in mortality \\
\hline$[62]$ & $\begin{array}{l}\text { Residents of } \\
\text { Kuala Lampur } \\
\text { Malaysia }\end{array}$ & $\begin{array}{l}\text { Variable with PM10 } \\
\text { above } 166 \text { on } 20 \\
\text { days and above } 245 \\
\text { on } 8 \text { days }\end{array}$ & $\begin{array}{l}\text { Episodic } \\
\text { over } \\
\text { several } \\
\text { months }\end{array}$ & $\begin{array}{c}\text { Increase in non-traumatic death with PM10 }>210 \\
\mathbf{7 0 \%} \text { (age 65-74) } \\
19 \% \text { (all ages) }\end{array}$ \\
\hline [57] & $\begin{array}{l}\text { Residents of } \\
\text { Indonesia }\end{array}$ & Not available & $\sim 4$ months & $\begin{array}{c}\text { Census data indicate } 15,600 \text { child, infant, and fetal } \\
\text { deaths, a } 1.2 \% \text { decrease in survival of those born or } \\
\text { expected to be born during period of exposure }\end{array}$ \\
\hline
\end{tabular}

*COPD = chronic obstructive pulmonary disease

When outdoor air particle concentrations increase, indoor air concentrations of particles also increase, particularly in homes because they usually have low efficiency particle filtration systems or no particle filtration. Based on analyses for a set of Boston-area homes [63], increases in indoor particle concentrations during wildfires will be between $49 \%$ and $76 \%$ of the increases in outdoor air particles, with the range dependent on particle size for particles between 0.25 and $5 \mu \mathrm{m}$ in diameter. Based on modeling by Riley et al. [64], increases in indoor particle concentrations will be $33 \%$ to $44 \%$ of increases in in outdoor particle concentrations for California homes with central air heating or cooling systems when windows are closed. The percentages are $64 \%$ to $80 \%$ for homes with typical air infiltration and no central air heating or cooling systems and $83 \%$ to $95 \%$ for homes with open windows. Their modeling suggest $53 \%$ to $72 \%$ increases in particles in offices with low efficiency particle filters and $13 \%$ to $18 \%$ increases in offices with high efficiency particle filters, relative to the increases in particles outdoors. The lower percentages and upper percentages in each range apply for PM10 and PM2.5, respectively.

Because people in the U.S. and many other developed countries are indoors approximately $90 \%$ of the time [65-67], and may be indoors even more when outdoor air is affected by wildfires, increases in exposures to particles from wildfires attributable to $\mathrm{CC}$ will occur primarily indoors. Thus, the adverse health effects expected from increased wildfires will substantially be the consequence of exposures to particles that penetrate to and persist indoors. Based on the discussion in the prior paragraph, in developed countries, increases in indoor concentrations of particles from wildfires are roughly $50 \%$ of the increases in outdoor concentrations. Combining this percentage with the $90 \%$ of the time that 
people in the U.S. are indoors, and accounting for the higher breathing rates when people are outdoors [68], one can estimate that, in adults, roughly $65 \%$ of total inhalation intake of particles from wildfires will occur when people are indoors. For children, the calculations indicate that about $50 \%$ of inhalation intake occurs indoors. These estimates are calculated using the approach presented in equations 2 and 3 of a paper by Weschler [68]. The most affected population (infants, the elderly, and those with respiratory diseases) are often indoors more than $90 \%$ of the time, increasing the significance of indoor exposures. If adverse health effects of wildfires scale directly with the total increase in inhalation particle intake, the proportion of adverse health effects of wildfires in the U.S. attributable to indoor exposures is roughly $65 \%$ for adults and $50 \%$ for children. However, it is possible that health effects are not linearly proportional to the total increase of particle intake, causing indoor exposures to account for a smaller fraction of the adverse health effects.

Based on the information in the preceding paragraph, it is clear that the health effects of indoor exposures to particles from wildfires are important, and are likely larger than the effects of exposures to these particles that occur when people are outdoors. Particularly vulnerable populations include the elderly, infants, people with cardiac and respiratory diseases who are more susceptible to health effects of particles $[69,70]$ and occupants of homes without air conditioning who are more likely to maintain open windows during warm weather. There are associated options to reduce the health effects of pollutants from wildfires. These options include doing the following when air is polluted by emissions from wildfires: 1) spending more time indoors; 2) keeping windows and doors closed; and 3) operating particle filtration systems. The particle filtration systems could be those installed in forced-air heating and cooling systems, with fans operated continuously when there is pollution from wildfires. To be highly effective for particles from wildfires, the filters installed in these systems should have a higher particle removal efficiency than is typical of current practice in U.S. homes [71]. Alternately, portable fan-filter systems (particle air cleaners) could be operated during wildfires. Modeling indicates that indoor PM2.5 concentrations of particles from wildfires could be decreased by $50 \%$ or more with filtration systems $[64,71,72]$. Routine use of either of these particle filter systems would also be expected to yield health benefits from reduced exposures to everyday sources of particles [72].

\subsection{Ozone}

Ozone is an important air pollutant produced in the outdoor air through chemical reactions of volatile organic compounds and nitrogen oxides in the presence of ultraviolet light from the sun. The chemical reaction rates, hence the ozone production rate, increase with temperature; thus, if all other factors were unchanged outdoor air ozone levels would increase as temperatures increase. However, ozone is not stable and the natural ozone destruction rate also increases with temperature. The IPCC projects that temperature increases from $\mathrm{CC}$ will reduce global-average tropospheric ozone but increase ozone within and near urban areas where most people live [12]. Climate change may also modify ozone levels in urban areas as a consequence of changes in air movement, cloud cover, humidity, and the emission rates of reactive volatile organic compounds and oxides of nitrogen. In some regions, simultaneous implementation of ozone control measures, as CC occurs, is likely to outweigh the effects of CC [73], leading to an overall reduction in ozone levels. However, in these cases CC would be expected to lessen the reductions in ozone levels.

Increased outdoor air ozone is linked to increases in a variety of adverse health effects including asthma, respiratory irritation, chronic obstructive pulmonary disease, hospitalizations, and mortality [68, 74-76]. Worldwide, approximately 150,000 premature deaths per year are attributable to ozone pollution [77] . While this number is large, it is much smaller than the projected number of deaths from exposures to particulate pollution [78]. Populations with increased susceptibility to adverse health effects from ozone 
include asthmatics, people with chronic obstructive pulmonary disease, the elderly, and people with cardiovascular disease [79-82]. Occupants of homes without air conditioning, who maintain windows open more often during warm weather will also have an increased vulnerability $[68,83,84]$.

Table 2 summarizes published estimates of how CC is anticipated to influence the health effects of outdoor ozone. To isolate the effects of changing climate, many studies have assumed no change in the emission rates of pollutants that are precursors to ozone and no changes in population. Table 2 only includes projections made while making these assumptions. The geographical regions and time periods considered, and the health outcomes evaluated, varied among the studies. Also, threshold concentrations above which ozone causes health effects varied among analyses from 0 to 40 parts per billion (ppb). The studies predict significant increases in mortality and hospital admission for respiratory health effects due to ozone if other factors such as emission rates of precursor pollutants are held constant. The predicted magnitudes of increases in health effects vary widely. Predicted percentage increases in daily total mortality range from $0.01 \%$ to $0.27 \%$, increases in the portion of total mortality caused by ozone range from $4.5 \%$ to $13.7 \%$, increases in total hospital admissions for specific respiratory health outcomes range from $0.24 \%$ to $2.1 \%$, and increases in ozone-caused hospital admissions or emergency-room visits for specific respiratory health effects range from $8.2 \%$ to $12.4 \%$. Some papers, e.g., $[85,86]$, show that changes in emission rates of pollutants that are precursors to ozone as a consequence or air pollution control activities, and changes in population, may strongly modify the extent to which CC increases the health effects of ozone; however, these results are not included in Table 2.

Because people in developed countries are indoors about $90 \%$ of the time, the health consequences of changes in ozone will partly be a consequence of changes in ozone levels inside buildings. Ozone reacts chemically with components of buildings and building furnishings [68, 87]. Ozone also reacts with some types of pollutants in indoor air. These reactions reduce indoor ozone levels to below outdoor air levels, unless strong indoor sources of ozone are present. The chemical reactions can produce new air pollutants that may possibly cause adverse health effects [68]; however, the health significance of many of the pollutants resulting from these reactions are poorly understood. Two of the pollutants produced are formaldehyde and ultrafine particles, and for both there is substantial evidence of adverse health effects.

Accounting for the differences between indoor and outdoor air ozone concentrations, Weschler [68] has estimated that indoor exposures to ozone are typically $45 \%$ to $75 \%$ of total exposures. Because peoples' breathing rates are lower when people are indoors, the amount of ozone inhaled when people are indoors is typically $25 \%$ to $60 \%$ of the total amount of ozone inhaled. These estimates may be low for the population most affected by ozone - the elderly, and those with respiratory and cardiovascular disease who are more often indoors. Consequently, if there is no threshold concentration for the health effects of ozone, or if the threshold is low, roughly half of the health effects resulting from increases in ozone with CC will be a consequence of increased indoor ozone concentrations.

Changes to buildings could diminish the adverse health effects of increases in ozone. Increased use of air conditioning and associated closing of windows are likely as the climate warms and could be encouraged when ozone levels are high. While air conditioning appears to pose some health risks [88-90], ozone concentrations are lower in air-conditioned buildings with closed windows. The ratio of indoor to outdoor air concentration in homes is typically 0.2 to 0.4 , but closer to 0.1 with air conditioning [68]. There is evidence that ozone less strongly affects health in cities with a higher prevalence of central air conditioning $[68,83]$, presumably because of less window opening and lower outdoor air ventilation 
rates during warm weather. In analyses for 18 U.S. cities, the increase in mortality per unit increase in outdoor air ozone concentration was smaller in cities with lower predicted annual average outdoor air ventilation rates in homes [91]. Filters containing activated carbon, through which air is passed using fans, can be effective in removing ozone for an extended period [92-95], although their current practicality for widespread residential application remains to be determined. Also, some types of building materials can passively (without fans) remove ozone and remove ozone more effectively if placed where fans increase indoor air motion. Pilot studies supplemented by modeling indicate that reductions in ozone concentrations can be as high as $30 \%$ with no fans and as high as $80 \%$ with fans used to increase air motion [96]. Subsequently modeled reductions in indoor ozone for a range of scenarios were 25 to 70\% [97]. Rates of passive ozone removal by activated carbon mats and perlitebased ceiling tiles decreased little over six months, with little production of undesirable pollutants [98]. However, the practicality of these passive ozone removal systems needs further evaluation. To reduce indoor ozone concentrations by $50 \%$ in a typical single family home, it may be necessary to install approximately $100 \mathrm{~m}^{2}$ of material that passively removes ozone at a high rate [97]. Overall, however, it is clear that actions taken in buildings could substantially reduce the adverse health effects expected from increases in ozone with CC. These actions would be expected to yield ozone-related health benefits even in the absence of CC.

Table 2. Projected changes in health effects of increases in ozone from climate change.

\begin{tabular}{|c|c|c|c|c|c|}
\hline Reference & Location & $\begin{array}{l}\text { Time } \\
\text { Period }\end{array}$ & Changes in ozone & $\begin{array}{c}\text { Key } \\
\text { Assumptions }\end{array}$ & Projected Increases in Health Effects \\
\hline [99] & 50 U.S. cities & $\begin{array}{l}2050 s \\
\text { versus } \\
1990 s\end{array}$ & $\begin{array}{l}\text { In summer: } \\
+4.8 \mathrm{ppb}, 1 \text { hour } \\
\max \\
+4.4 \mathrm{ppb}, 8 \text {-hour } \\
\max \end{array}$ & $\begin{array}{l}\text { No changes in } \\
\text { ozone } \\
\text { precursors and } \\
\text { population }\end{array}$ & $\begin{array}{l}\text { Daily total mortality in summer: } 0.11 \% \text { to } 0.27 \% \\
\text { Daily total hospital admissions in summer from: } \\
\text { COPD* } 0.24 \% \text { to } 1.6 \% \text {, age } \geq 65 \\
\text { Respiratory effects } 0.8 \% \text { to } 2.1 \% \text {, age } \geq 65 \\
\text { Asthma } 2.1 \% \text {, age } \leq 64\end{array}$ \\
\hline [100] & $\begin{array}{l}19 \text { cities in } \\
\text { U.S. } \\
\text { southeast }\end{array}$ & $\begin{array}{l}2040 s \\
\text { versus } \\
2000\end{array}$ & $\begin{array}{l}0.43 \mathrm{ppb} \text {, annual } \\
\text { average }\end{array}$ & $\begin{array}{l}\text { No change in } \\
\text { ozone } \\
\text { precursors and } \\
\text { population }\end{array}$ & $\begin{array}{l}\text { Total annual mortality rate: } \\
0.01 \%\end{array}$ \\
\hline [101] & $\begin{array}{l}\text { New York } \\
\text { City } \\
\text { Metropolitan } \\
\text { area }\end{array}$ & $\begin{array}{l}\text { 2050s } \\
\text { vs. } \\
1990 s\end{array}$ & $\begin{array}{l}0.3 \text { to } 4.3 \mathrm{ppb} \\
\text { increase in } \\
\text { summer average } \\
\text { 1-h maximum } \\
\text { (varies with } \\
\text { location) }\end{array}$ & $\begin{array}{l}\text { No changes in } \\
\text { ozone } \\
\text { precursors or } \\
\text { population }\end{array}$ & $\begin{array}{l}\text { Median } 4.5 \% \text { increase in ozone-related mortality in } \\
\text { summer } \\
\text { Slightly larger percentage increase in deaths if health } \\
\text { models assumes no health effects of ozone less than } 20 \\
\text { ppb }\end{array}$ \\
\hline [85] & $\begin{array}{l}27 \text { countries } \\
\text { in Europe }\end{array}$ & $\begin{array}{l}2021- \\
2050 \\
\text { versus } \\
1961- \\
1990 \\
\\
\end{array}$ & $\begin{array}{l}\text { Not available } \\
\text { (Paper provides } \\
\text { total change in } \\
\text { product of } \\
\text { concentration and } \\
\text { time) }\end{array}$ & $\begin{array}{c}1.9 \text { to } 2.1^{\circ} \mathrm{C} \\
\text { increase in } \\
\text { temperature } \\
\text { No changes in } \\
\text { ozone } \\
\text { precursors or } \\
\text { population; no } \\
\text { health effects } \\
\text { for }<35 \mathrm{ppb} \\
\\
\text { Temperature } \\
\text { change for } \\
2041-2060 \text { not } \\
\text { provided }\end{array}$ & $\begin{array}{l}8.6 \% \text { to } 13.7 \% \text { ( } 2402 \text { to } 3543 \text { ) increase in annual ozone- } \\
\text { related mortality } \\
8.2 \% \text { to } 12.4 \% \text { ( } 3135 \text { to } 4402) \text { increase in annual ozone- } \\
\text { related hospitalizations }\end{array}$ \\
\hline [102] & $\begin{array}{l}\text { Sydney, } \\
\text { Australia }\end{array}$ & $\begin{array}{l}2051- \\
2060 \\
\text { versus } \\
1996- \\
2005\end{array}$ & $\begin{array}{l}\text { Daily } 1 \text {-hour } \\
\text { maximum } \\
\text { increase is } 0.89 \text { to } \\
1.05 \mathrm{ppb}\end{array}$ & $\begin{array}{l}\text { No changes in } \\
\text { ozone } \\
\text { precursors and } \\
\text { population } \\
\text { Three CC }\end{array}$ & $\begin{array}{l}\text { In Sydney with population of } 4.1 \text { million, deaths per } \\
\text { decade from ozone increase by: } \\
60 \text { with no threshold for health effects of ozone } \\
65 \text { with } 25 \mathrm{ppb} \text { threshold for health effects of ozone } \\
55 \text { with } 40 \mathrm{ppb} \text { threshold for health effects of ozone }\end{array}$ \\
\hline
\end{tabular}




\begin{tabular}{|l|l|l|l|l|l|}
\hline & & & & scenarios & \\
\hline$[103]$ & $\begin{array}{l}\text { New York } \\
\text { City } \\
\text { Metropolitan } \\
\text { area }\end{array}$ & $\begin{array}{l}\text { 2020s } \\
\text { versus } \\
1990 \mathrm{~s}\end{array}$ & $\begin{array}{l}\text { Average summer } \\
\text { 8-hour maximum } \\
\text { increases by 2.7 - } \\
5.3 \text { ppb depending } \\
\text { on location }\end{array}$ & $\begin{array}{l}\text { No change in } \\
\text { ozone } \\
\text { precursors and } \\
\text { population } \\
\text { (base case } \\
\text { analysis) }\end{array}$ & $\begin{array}{l}\text { Ozone-related emergency room visits in summer of } \\
\text { children (age 0-17) for asthma increase by 56 (7.3\%) }\end{array}$ \\
\hline$[104]$ & $\begin{array}{l}\text { United } \\
\text { States }\end{array}$ & $\begin{array}{l}2050 \\
\text { versus } \\
2001\end{array}$ & $\begin{array}{l}\text {-3.8 to 5.4 ppb in } \\
\text { annual average } \\
\text { ozone depending } \\
\text { on location }\end{array}$ & $\begin{array}{l}\text { No change in } \\
\text { ozone } \\
\text { precursors and } \\
\text { population }\end{array}$ & $\begin{array}{l}\text { Mean predicted annual increases in number of cases: } \\
\text { acute respiratory symptom days = 4.6 million; } \\
\text { respiratory emergency room visits = 1618; school loss } \\
\text { days = 1.4 million }\end{array}$ \\
\hline
\end{tabular}

\subsection{Indicated Mitigation Measures to Protect IEQ}

The preceding analysis identified various measures to reduce the projected IEQ-related adverse health effects of CC. Some of these measures will reduce greenhouse gas emissions, or are projected to improve health even in the absence of CC. A list of these measures is compiled in Table 3. The listed measures can be considered no-regret measures because the projected benefits occur irrespective of CC. In most cases suitable technologies or practices are available today. Increased research can better develop the measures and assess their effectiveness, with research most needed on the ozone mitigation measures. Implementation of mitigation measures can be targeted at the homes of the most vulnerable populations such as the elderly, infants, people with pre-existing respiratory or cardiovascular disease, and people in homes without air conditioning.

Table 3. Indicated no-regrets mitigation measures for IEQ.

\begin{tabular}{|c|c|c|c|}
\hline Measure & Protects Against: & $\begin{array}{c}\text { Reduces } \mathrm{CO}_{2} \\
\text { Emissions? }\end{array}$ & $\begin{array}{c}\text { Expected Health } \\
\text { Benefits Irrespective } \\
\text { of Climate Change? }\end{array}$ \\
\hline $\begin{array}{c}\text { Thermal insulation of attics; Cool roofing materials; External } \\
\text { shading; Energy efficient windows }\end{array}$ & Heat waves & Yes & Yes \\
\hline $\begin{array}{c}\text { Building envelope design and construction practices to reduce the } \\
\text { potential for water entry; Improved maintenance of building } \\
\text { envelopes; Elevating buildings above grade level in flood-prone } \\
\text { locations; Locating fewer buildings in flood plains }\end{array}$ & $\begin{array}{c}\text { Severe storms and } \\
\text { sea level rise }\end{array}$ & Some-times & Yes \\
\hline $\begin{array}{c}\text { Improvements in particle filtration } \\
\text { wildfires }\end{array}$ & No* & Yes \\
\hline Filters containing activated carbon; Building materials that \\
passively reduce indoor ozone
\end{tabular}

*some measures will marginally increase building energy consumption and related $\mathrm{CO}_{2}$ emissions

\subsection{Building Energy Efficiency}

Between $30 \%$ and $40 \%$ of carbon dioxide emissions in the U.S. and Europe $[105,106]$ are attributable to building energy use; therefore, building energy efficiency is a key CC mitigation strategy. Goals within the U.S., Europe, and some other countries include large magnitude and broad-based improvements in building energy efficiency. Some building energy efficiency measures implemented to help mitigate climate change have the potential to improve and/or degrade indoor comfort conditions, indoor air quality, and people's health [107-109]. Among the many building energy efficiency measures that may affect IEQ and health, three residential energy efficiency measures are discussed in this section because they are very common: air tightening of residential building envelopes, improvements in the thermal insulation of residential building envelopes, and aggressive multifaceted efforts to make new homes very energy efficient. 
In residential energy retrofits, building envelopes are often tightened without addition of mechanical ventilation. Building envelope air tightening reduces air infiltration rates. Without compensating measures, indoor air concentrations of some air pollutants from the outdoor air, most notably ozone and particles, will be diminished as infiltration rates are reduced by air tightening of building envelopes $[110,111]$. It is logical to expect an associated reduction in a variety of adverse health effects that are associated with outdoor air particles and ozone $[68,69]$; however, these health benefits have not been empirically demonstrated. At the same time, the reductions in air infiltration rates will increase indoor air concentrations of indoor-generated air pollutants emitted from indoor sources and increase associated health risks. While reductions in ventilation rates in offices have been associated with increases in adverse health symptoms [112]; data relating residential ventilation rates with health are extremely limited $[1,113]$ with a few studies suggesting increases in allergy and asthma outcomes with low ventilation rates [1]. The risks of chronic health effects from reductions in ventilation rates in homes can be predicted with models but only one associated published paper was identified. Milner et al. [114] estimated that increases in air tightness in England, without compensating measures, would increase indoor radon concentrations by $57 \%$ with an associated peak increase of 278 deaths per year. At present, the net health effects from envelope tightening that reduce indoor exposures to outdoor air pollutants and increase exposures to indoor-generated pollutants are not known

Indoor air humidity will also be affected by envelope air tightening. When the outdoor air moisture content exceeds the indoor air moisture content, because of an indoor air dehumidification process, air tightening will often reduce indoor air humidity. With decreased humidity, levels of dust mites and dust mite allergen, will often be reduced [115-117]. Dust mite allergen is associated with allergies and asthma [118]. The risks of indoor dampness and mold growth, associated with respiratory and asthma symptoms [40] are diminished by avoiding high indoor humidity values and the indoor levels of formaldehyde will be reduced because indoor formaldehyde emission rates decrease with decreased indoor humidity [119]. On the other hand, during the heating season when the moisture content of indoor air is often higher than the moisture content of outdoor air, envelope air tightening, without compensating measures, will increase indoor air humidity. Consequently, dust mite levels, dampness and mold risks, formaldehyde levels, and associated health risks, would be expected to increase.

Indoor thermal comfort conditions may be changed by envelope tightening. In the winter, cold drafts associated with air leakage will be diminished. In hot summer weather, in buildings without air conditioning, indoor comfort is expected to sometimes improve because the rate of heat gain from outdoors is reduced. However, during moderate weather the risk of indoor overheating is increased because internally-generated heat is more slowly dissipated to outdoors. These effects are largely based on theory and anecdotal data - no large sets of published systematic data were identified.

Adding thermal insulation to the building envelope is another very common residential retrofit measure with implications for IEQ. Insulation of the envelope and envelope tightening are often implemented as a package, often together with other weatherization measures such as installation of more energy efficient heating and cooling systems and windows. It is widely claimed and logical to expect that retrofits that add thermal insulation will improve indoor thermal comfort at least during cold winter weather; however, minimal published confirmatory data were identified. Data from a study of 79 U.S. homes [120] suggest about a $0.5^{\circ} \mathrm{C}$ increase in temperature after retrofits, implying a modest increase in winter-time comfort. A larger study in the United Kingdom reported an increase in average indoor temperature from 17.1 to $19.0{ }^{\circ} \mathrm{C}$ and a rise in percentage of households reporting comfortable or warmer conditions from $36 \%$ to $79 \%$, after adding thermal insulation and also replacing the heating 
systems with an energy efficient heating system. A study of adding thermal insulation to homes serving a low income population in New Zealand also provides evidence of improvements in temperatures, comfort and several health or health-related outcomes (self-reported colds and flu, wheeze, sleep disturbed by wheeze, visits to a general practitioner, and days of missed work and school) [121, 122]. However, there was a large reported decrease in mold in the homes after addition of insulation; thus, it is not certain that the improvements in health are a consequence of the increases in indoor air temperature, which were modest, averaging $0.5^{\circ} \mathrm{C}\left(1^{\circ} \mathrm{F}\right)$. Also, relative to temperatures in homes in North America and Europe, indoor temperatures in the New Zealand study population were low, averaging less than $14{ }^{\circ} \mathrm{C}\left(57^{\circ} \mathrm{F}\right)$ in the bedroom. Thus, the available data suggest, but do not confirm, widespread health benefits of adding thermal insulation.

The summertime comfort and health implications of adding thermal insulation are less consistent. In air conditioned homes, increased insulation will make it easier to maintain comfortable indoor temperatures throughout the home. However, indoor humidity may rise because the air conditioning system, which removes moisture from indoor air, operates less frequently in a well-insulated (and air tight) home. If the home is not air conditioned, addition of insulation will often reduce peak indoor temperatures. However, insulation also slows the rate of heat loss from indoors to outdoors, which could lead to periods of overheating. In particular, a highly insulated home will not cool down as much at night following hot day. As discussed in section 3.1, models suggest that attic or roof insulation will generally protect against heat stress during heat waves, but interior wall insulation can increase indoor heat stress risks.

In addition to energy efficiency retrofits, a broad portfolio of measures are sometime employed to make new homes much more energy efficient than typical existing homes. These measures include, but are not limited to, very air tight envelopes, provision of mechanical ventilation, high levels of envelope insulation, and energy efficient heating and air conditioning systems. In some instances, there are simultaneous measures undertaken to reduce indoor pollutant sources. There are potential positive and negative IEQ and health implications of making new homes highly energy efficient $[107,108]$ with the resulting net outcome for health very uncertain and dependent on the measures implemented and outdoor climatic and air quality conditions. One key concern is the often poor performance or lack of use of residential mechanical ventilation systems, reported in several studies [107, 108, 123].

\subsection{CONCLUSIONS}

Climate change-related increases in heat waves, severe storms, sea level, wildfires, and ozone will result in substantial adverse health effects. Based on the available evidence, the projected health effects are, to a substantial extent, a consequence of indoor exposures. The elderly, infants, people with respiratory and cardiac diseases, and residents of homes without air conditioning are particularly vulnerable. Adverse health effects can be reduced by changes in features of buildings and building operation. Many of these changes to buildings are expected to also improve health even without CC. In addition, some of the measures reduce building energy use and associated carbon dioxide emissions.

Building energy efficiency, which will be increasingly implemented to mitigate climate change, can improve or degrade IEQ and health. The resulting net effects on health are very uncertain and will depend on the measures implemented and outdoor climatic and air quality conditions.

Substantial uncertainties remain. The extent of CC is uncertain and will depend on the extent to which mitigation measures are implemented. The projected health effects will depend not only on the extent of CC, but on changes in population, on implementation of policies and practices irrespective of climate 
change, and on the implementation of $\mathrm{CC}$ adaptation measures. The relationships of exposures to health effects remain uncertain, although the uncertainties generally apply to the magnitudes of health effects, not to the existence of health effects. Despite these uncertainties, many of the mitigation measures remain attractive because their benefits would be widespread and occur irrespective of CC.

Research is needed to address the uncertainties and to further develop and test mitigation measures that could be applied in buildings to reduce the adverse health effects of CC. Examples include: research to determine how indoor heat-related climatic conditions, as opposed to outdoor conditions, affect health; tests of the effects of thermal insulation and cool roof coatings on indoor thermal conditions; further development and evaluation of technologies for reducing indoor ozone concentrations; and broad-based systematic studies of the effects of building energy efficiency on indoor environmental quality and health.

\subsection{ACKNOWLEDGMENTS}

This study was funded through interagency agreement DW- 89-92337001 between the Indoor Environments Division, Office of Radiation and Indoor Air of the U.S. Environmental Protection Agency (EPA) and the U. S. Department of Energy under contract DE-AC02-05CH11231, to develop an IAQ Scientific Findings Resource Bank (see www.iaqscience.lbl.gov). Conclusions in this paper are those of the author and not necessarily those of the U.S. EPA. The author thanks Greg Brunner for program management, and Greg Brunner, William Nazaroff, Rengie Chan, and Laura Kolb for reviewing a draft of a document on which this paper is based.

\subsection{REFERENCES}

[1] IOM. Climate change, the indoor environment, and health. Washington, D.C.: The National Academies Press; 2011.

[2] Spengler JD. Climate change, indoor environments, and health. Indoor Air. 2012;22:89-95.

[3] Nazaroff WW. Exploring the consequences of climate change for indoor air quality. Environmental Research Letters. 2013;8:015022.

[4] Smith KR, Woodward A, Cambell-Lendrum D, Chadee DD, Honda Y, Liu Q, et al. Human health: impacts, adaptation, and co-benefits. . In: Climate change 2014: impacts, adaptation, and vulnerability Part A: global and sectoral aspects Contribution of Working Group II to the Fifth Assessment Report of the Intergovernmental Panel on Climate Change. Cambride University Press, Cambridge, United Kingdon2014.

[5] IPCC. Climate change 2013, the physical science basis, Working Group 1 contribution to the IPCC 5th Assessment Report, Final draft underlying scientific-technical assessment. Geneva, Switzerland: Intergovernmental Panel on Climate Change; 2013.

[6] Wu J, Zhou Y, Gao Y, Fu JS, Johnson BA, Huang C, et al. Estimation and uncertainty analysis of impacts of future heat waves on mortality in the Eastern United States. Environ Health Perspect. 2013.

[7] Melillo JM, Richmond T. C. , Yohe G. W. , Eds.,. Climate change impacts in the United States: the third national climate assessment. Washington, D. C.: U.S. Global Change Research Program; 2014.

[8] California EPA. Preparing California for extreme heat, guidance and recommendations. Sacramento, CA: California Envirinmental Protection Agency; 2013.

[9] Guirguis K, Gershunov A, Tardy A, Basu R. The impact of recent heat waves on human health in California. Journal of Applied Meteorology and Climatology. 2013;53:3-19. 
[10] Confalonieri U, Menne B, Akhtar R, Ebi KL, Hauengue M, Kovats RS, et al. Human health. Climate Change 2007: Impacts, Adaptation and Vulnerability Contribution of Working Group II to the Fourth Assessment Report of the Intergovernmental Panel on Climate Change. 2007.

[11] Staddon PL, Montgomery HE, Depledge MH. Climate warming will not decrease winter mortality. Nature Climate Change. 2014;DOO:10.1038/NCLIMATE2121.

[12] IPCC. Climate Change 2014 "impacts, adaptation, and vulnerability, Chapter 11.

http://www.ipcc.ch/report/ar5/wg2/ [Accessed November 2014].

[13] Ebi KL, Mills D. Winter mortality in a warming climate: a reassessment. Wiley Interdisciplinary Reviews: Climate Change. 2013;4:203-12.

[14] Huang C, Barnett AG, Wang X, Vaneckova P, FitzGerald G, Tong S. Projecting future heat-related mortality under climate change scenarios: a systematic review. Environ Health Perspect. 2011;119:168190.

[15] D'Ippoliti D, Michelozzi P, Marino C, de'Donato F, Menne B, Katsouyanni K, et al. Research The impact of heat waves on mortality in 9 European cities: results from the EuroHEAT project.

Environmental Health. 2010;9:http://www.ehjournal.net/content/9/1/37.

[16] Fouillet A, Rey G, Wagner V, Laaidi K, Empereur-Bissonnet P, Le Tertre A, et al. Has the impact of heat waves on mortality changed in France since the European heat wave of summer 2003? A study of the 2006 heat wave. International Journal of Epidemiology. 2008;37:309-17.

[17] Fouillet A, Rey G, Laurent F, Pavillon G, Bellec S, Guihenneuc-Jouyaux C, et al. Excess mortality related to the August 2003 heat wave in France. Int Arch Occup Environ Health. 2006;80:16-24.

[18] McGeehin MA, Mirabelli M. The potential impacts of climate variability and change on temperature-related morbidity and mortality in the United States. Environ Health Perspect. 2001;109 Suppl 2:185-9.

[19] Stafoggia M, Forastiere F, Agostini D, Biggeri A, Bisanti L, Cadum E, et al. Vulnerability to heatrelated mortality: a multicity, population-based, case-crossover analysis. Epidemiology. 2006;17:315-23. [20] Centers for Disease Control and Prevention. Heat illness and deaths - New York City, 2000-2011. MMWR. 2013;62:617-21.

[21] Klepeis NE, Tsang AM, Behar JV. Analysis of the National Human Activity Pattern Survey (NHAPS) respondents from a standpoint of exposure assessment. Las Vegas, NV: National Exposure Research Laboratory, U.S. Environmental Protection Agency; 1995.

[22] Lanki T, Ahokas A, Alm S, Janssen NA, Hoek G, De Hartog JJ, et al. Determinants of personal and indoor PM2. 5 and absorbance among elderly subjects with coronary heart disease. Journal of Exposure Science and Environmental Epidemiology. 2006;17:124-33.

[23] Vandentorren S, Bretin P, Zeghnoun A, Mandereau-Bruno L, Croisier A, Cochet C, et al. August 2003 heat wave in France: risk factors for death of elderly people living at home. European journal of public health. 2006;16:583-91.

[24] World Health Organization Regional Office for Europe. Improving public health responses to extreme weather/heat waves - technical summary. Copenhagen: World Health Organization Regional Office for Europe; 2009.

[25] Ostro B, Rauch S, Green R, Malig B, Basu R. The effects of temperature and use of air conditioning on hospitalizations. Am J Epidemiol. 2010;172:1053-61.

[26] Mavrogianni A, Davies M, Taylor J, Chalabi Z, Biddulph P, Oikonomou E, et al. The impact of occupancy patterns, occupant-controlled ventilation and shading on indoor overheating risk in domestic environments. Building and Environment. 2014;78:183-98.

[27] Mavrogianni A, Wilkinson P, Davies M, Biddulph P, Oikonomou E. Building characteristics as determinants of propensity to high indoor summer temperatures in London dwellings. Building and Environment. 2012;55:117-30. 
[28] Gupta R, Gregg M. Using UK climate change projections to adapt existing English homes for a warming climate. Building and Environment. 2012;55:20-42.

[29] Porritt SM, Cropper PC, Shao L, Goodier Cl. Heat wave adaptations for UK dwellings and development of a retrofit toolkit. International Journal of Disaster Resilience in the Built Environment. 2013;4:269-86.

[30] Porritt SM, Cropper PC, Shao L, Goodier Cl. Ranking of interventions to reduce dwelling overheating during heat waves. Energy and Buildings. 2012;55:16-27.

[31] Lee WV, Steemers K. Accounting for Exposure Duration in Overheating Risk Assessment--A Chicago Retrofit Case Study. ASHRAE Transactions. 2013;119.

[32] Lomas K, Kane T. Summertime temperatures in 282 UK homes: thermal comfort and overheating risk. Proceedings of 7 th Windsor Conference: The changing context of comfort in an unpredictable world2012.

[33] Anderson M, Carmichael C, Murray V, Dengel A, Swainson M. Defining indoor heat thresholds for health in the UK. Perspectives in public health. 2013;133:158-64.

[34] IPCC. Summary for policymakers. In: Climate Change 2013: The Physical Science Basis. Contribution of Working Group I to the Fifth Assessment Report of the Intergovernmental Panel on Climate Change. In: Stocker T.F., D. Qin D., Plattner G.-K., Tignor M., Allen S.K., Boschung J., et al., editors. Cambridge: Intergovernmental Panel on Climate Change; 2013.

[35] EPA. Climate change indicators in the United States, 2014 third edition. Washington, DC: U.S. Environmental Protection Agency; 2014.

[36] Nicholls RJ, Cazenave A. Sea-level rise and its impact on coastal zones. Science. 2010;328:1517-20.

[37] Mousavi ME, Irish JL, Frey AE, Olivera F, Edge BL. Global warming and hurricanes: the potential impact of hurricane intensification and sea level rise on coastal flooding. Climatic Change. 2011;104:575-

97.

[38] Tebaldi C, Strauss BH, Zervas CE. Modelling sea level rise impacts on storm surges along US coasts. Environmental Research Letters. 2012;7:014032.

[39] IOM. Damp indoor spaces and health, Institute of Medicine, National Academy of Sciences. Washington, D.C.: National Academy Press; 2004.

[40] Fisk WJ, Lei-Gomez $Q$, Mendell MJ. Meta-analyses of the associations of respiratory health effects with dampness and mold in homes. Indoor Air. 2007;17:284-95.

[41] Mendell MJ, Mirer AG, Cheung K, Tong M, Douwes J. Respiratory and allergic health effects of dampness, mold, and dampness-related agents: a review of the epidemiologic evidence. Environ Health Perspect. 2011;119:748-56.

[42] Fisk WJ, Eliseeva E, Mendell MJ. Association of residential dampness and mold with respiratory tract infections and bronchitis: a meta-analysis. Environmental Health. 2010;9:72.

[43] Mudarri D, Fisk WJ. Public health and economic impact of dampness and mold. Indoor Air. 2007;17:226-35.

[44] Fisk WJ, Black D, Brunner G. Benefits and costs of improved IEQ in offices. Indoor Air. 2011;21:35767.

[45] Sahakian N, Park JH, Cox-Ganser J. Respiratory morbidity and medical visits associated with dampness and air-conditioning in offices and homes. Indoor Air. 2009;19:58-67.

[46] Lstiburek JW. Understanding drainage planes. ASHRAE Journal. 2006;48:30-5.

[47] Lstiburek JW, Carmody J. Moisture control handbook: principles and practices for residential and small commercial buildings. New York: Van Nostrand Reinhold; 1993.

[48] Carll C. Rainwater intrusion in light-frame building walls. Proceedings of the 2 nd Annual Conference on Durability and Disaster Mitigation in Wood-Frame Housing: November2000. p. 6-8. 
[49] Spracklen DV, Mickley L, Logan JA, Hudman RC, Yevich R, Flannigan MD, et al. Impacts of climate change from 2000 to 2050 on wildfire activity and carbonaceous aerosol concentrations in the western United States. J Geophys Res-Atmos. 2009;114.

[50] Dawson JP, Bloomer BJ, Winner DA, Weaver CP. Understanding the meteorological drivers of US particulate matter concentrations in a changing climate. Bulletin of the American Meteorological Society. 2013:http://dx.doi.org/10.1175/BAMS-D-12-00181.1.

[51] Kirtman B, Power SB, Adedoyin JA, Bore GJ, Bojariu R, Camilloni I, et al. Near-term climate change: projections and predictability. In: Stocker T.F., Qin D., Plattner G.-K., Tignor M., Allen S.K., Boschung J., et al., editors. Climate change 2013: the physical science basis contribution of Working Group I to the fifth assessment report of the Intergovernmental Panel on Climate Change. Cambridge, United Kingdom: Cambride University Press; 2014.

[52] Delfino RJ, Brummel S, Wu J, Stern H, Ostro B, Lipsett M, et al. The relationship of respiratory and cardiovascular hospital admissions to the southern California wildfires of 2003. Occupational and Environmental Medicine. 2009;66:189-97.

[53] Wu J, Winer AM, Delfino RJ. Exposure assessment of particulate matter air pollution before, during, and after the 2003 Southern California wildfires. Atmospheric Environment. 2006;40:3333-48.

[54] Künzli N, Avol JW, Gauderman WJ, Rappaport JM, Bennion J, McConnell R, et al. Health effects of the 2003 Southern California wildfires on children. American journal of respiratory and critical care medicine. 2006;174:1221.

[55] Na K, Cocker DR. Fine organic particle, formaldehyde, acetaldehyde concentrations under and after the influence of fire activity in the atmosphere of Riverside, California. Environmental research. 2008;108:7-14.

[56] Finlay SE, Moffat A, Gazzard R, Baker D, Murray V. Health impacts of wildfires. PLoS Currents. 2012;4.

[57] Jayachandran S. Air quality and early-life mortality evidence from Indonesia's wildfires. Journal of Human Resources. 2009;44:916-54.

[58] Frankenberg E, McKee D, Thomas D. Health consequences of forest fires in Indonesia. Demography. 2005;42:109-29.

[59] EPA. National ambient air quality standards (NAAQS). : United States Environmental Protection Agency Available from: http://www.epa.gov/air/criteria.html [accessed November 2014]

[60] Vedal S, Dutton SJ. Wildfire air pollution and daily mortality in a large urban area. Environmental Research. 2006;102:29-35.

[61] Moore D, Copes R, Fisk R, Joy R, Chan K, Brauer M. Population health effects of air quality changes due to forest fires in British Columbia in 2003. Canadian Journal of Public Health. 2006;97:105-8.

[62] Sastry N. Forest fires, air pollution, and mortality in Southeast Asia. Demography. 2002;39:1-23.

[63] Bennett D, Koutrakis P. Determining the infiltration of outdoor particles in the indoor environment using a dynamic model. Journal of Aerosol Science. 2006;37:766-85.

[64] Riley WJ, McKone TE, Lai AC, Nazaroff WW. Indoor particulate matter of outdoor origin: importance of size-dependent removal mechanisms. Environ Sci Technol. 2002;36:200-7.

[65] Klepeis NE, Nelson WC, Ott WR, Robinson JP, Tsang AM, Switzer P, et al. The National Human Activity Pattern Survey (NHAPS): a resource for assessing exposure to environmental pollutants. Journal of exposure analysis and environmental epidemiology. 2001;11:231-52.

[66] Leech JA, Nelson WC, Burnett RT, Aaron S, Raizenne ME. It's about time: a comparison of Canadian and American time-activity patterns. Journal of Exposure Analysis and Environmental Epidemiology. 2002;12:427-32. 
[67] Schweizer C, Edwards RD, Bayer-Oglesby L, Gauderman WJ, llacqua V, Jantunen MJ, et al. Indoor time-microenvironment-activity patterns in seven regions of Europe. Journal of Exposure Science and Environmental Epidemiology. 2006;17:170-81.

[68] Weschler CJ. Ozone's impact on public health: contributions from indoor exposures to ozone and products of ozone-initiated chemistry. Environ Health Perspect. 2006;114:1489-96.

[69] Pope CA, 3rd, Dockery DW. Health effects of fine particulate air pollution: lines that connect. J Air Waste Manag Assoc. 2006;56:709-42.

[70] Bell ML, Ebisu K, Peng RD, Dominici F. Adverse Health Effects of Particulate Air Pollution Modification by Air Conditioning. Epidemiology. 2009;20:682-6.

[71] Fisk WJ, Faulkner D, Palonen J, Seppanen O. Performance and costs of particle air filtration technologies. Indoor Air. 2002;12:223-34.

[72] Fisk WJ. Health benefits of particle filtration. Indoor Air. 2013;23:357-68.

[73] Kelly J, Makar P, Plummer D. Projections of mid-century summer air-quality for North America: effects of changes in climate and precursor emissions. Atmospheric Chemistry \& Physics Discussions. 2012;12.

[74] Levy JI, Carrothers TJ, Tuomisto JT, Hammitt JK, Evans JS. Assessing the public health benefits of reduced ozone concentrations. Environmental Health Perspectives. 2001;109:1215.

[75] Levy JI, Chemerynski SM, Sarnat JA. Ozone exposure and mortality: an empiric bayes metaregression analysis. Epidemiology. 2005;16:458-68.

[76] Bell ML, Peng RD, Dominici F. The exposure-response curve for ozone and risk of mortality and the adequacy of current ozone regulations. Environ Health Perspect. 2006;114:532-6.

[77] Lim SS, Vos T, Flaxman AD, Danaei G, Shibuya K, Adair-Rohani H, et al. A comparative risk assessment of burden of disease and injury attributable to 67 risk factors and risk factor clusters in 21 regions, 1990-2010: a systematic analysis for the Global Burden of Disease Study 2010. Lancet. 2012;380:2224-60.

[78] Lim SS, Vos T, Flaxman AD, Danaei G, Shibuya K, Adair-Rohani H, et al. A comparative risk assessment of burden of disease and injury attributable to 67 risk factors and risk factor clusters in 21 regions, 1990-2010: a systematic analysis for the Global Burden of Disease Study 2010. The Lancet. 2012;380:2224-60.

[79] Bernstein JA, Bobbitt RC, Levin L, Floyd R, Crandall MS, Shalwitz RA, et al. Health effects of ultraviolet irradiation in asthmatic children's homes. J Asthma. 2006;43:255-62.

[80] Medina-Ramón M, Schwartz J. Who is more vulnerable to die from ozone air pollution? Epidemiology. 2008;19:672-9.

[81] Stafoggia M, Forastiere F, Faustini A, Biggeri A, Bisanti L, Cadum E, et al. Susceptibility factors to ozone-related mortality: a population-based case-crossover analysis. American journal of respiratory and critical care medicine. 2010;182:376-84.

[82] Zanobetti A, Schwartz J. Ozone and survival in four cohorts with potentially predisposing diseases. American journal of respiratory and critical care medicine. 2011;184:836-41.

[83] Smith RL, Xu B, Switzer P. Reassessing the relationship between ozone and short-term mortality in U.S. urban communities. Inhal Toxicol. 2009;21 Suppl 2:37-61.

[84] Bell ML, Dominici F. Effect modification by community characteristics on the short-term effects of ozone exposure and mortality in 98 US communities. American journal of epidemiology. 2008;167:98697.

[85] Orru H, Andersson C, Ebi KL, Langner J, Astrom C, Forsberg B. Impact of climate change on ozonerelated mortality and morbidity in Europe. Eur Respir J. 2013;41:285-94.

[86] West JJ, Szopa S, Hauglustaine DA. Human mortality effects of future concentrations of tropospheric ozone. Comptes Rendus Geoscience. 2007;339:775-83. 
[87] Weschler CJ. Ozone in indoor environments: concentration and chemistry. Indoor Air. 2000;10:26988.

[88] Mendell MJ, Smith AH. Consistent pattern of elevated symptoms in air-conditioned office buildings: a reanalysis of epidemiologic studies. Am J Public Health. 1990;80:1193-9.

[89] Seppänen O, Fisk WJ. Association of ventilation system type with SBS symptoms in office workers. Indoor Air. 2002;12:98-112.

[90] Spengler JD, Neas L, Nakai S, Dockery DW, Speizer FE, Ware JH, et al. Respiratory symptoms and housing characteristics. Indoor Air. 1994;4:72-82.

[91] Chen C, Zhao B, Weschler CJ. Assessing the influence of indoor exposure to "outdoor ozone" on the relationship between ozone and short-term mortality in U.S. communities. Environ Health Perspect. 2012;120:235-40.

[92] Lee P, Davidson J. Evaluation of activated carbon filters for removal of ozone at the ppb level. American Industrial Hygiene Association Journal. 1999;60:589-600.

[93] Weschler CJ, Shields HC, Naik DV. Ozone-removal efficiencies of activated carbon filters after more than three years of continuous service. ASHRAE Transactions. 1994;100:1121-9.

[94] Beko G, Clausen G, Weschler CJ. Sensory pollution from bag filters, carbon filters and combinations. Indoor Air. 2008;18:27-36.

[95] Bekö G, Fadeyi MO, Clausen G, Weschler CJ. Sensory pollution from bag-type fiberglass ventilation filters: Conventional filter compared with filters containing various amounts of activated carbon. Building and Environment. 2009;44:2114-20.

[96] Kunkel DA, Gall ET, Siegel JA, Novoselac A, Morrison GC, Corsi RL. Passive reduction of human exposure to indoor ozone. Building and Environment. 2010;45:445-52.

[97] Gall ET, Corsi RL, Siegel JA. Barriers and opportunities for passive removal of indoor ozone. Atmospheric Environment. 2011;45:3338-41.

[98] Cros CJ, Morrison GC, Siegel JA, Corsi RL. Long-term performance of passive materials for removal of ozone from indoor air. Indoor Air. 2012;22:43-53.

[99] Bell ML, Goldberg R, Hogrefe C, Kinney PL, Knowlton K, Lynn B, et al. Climate change, ambient ozone, and health in 50 US cities. Climatic Change. 2007;82:61-76.

[100] Chang HH, Zhou J, Fuentes M. Impact of climate change on ambient ozone level and mortality in southeastern United States. International journal of environmental research and public health.

2010;7:2866-80.

[101] Knowlton K, Rosenthal JE, Hogrefe C, Lynn B, Gaffin S, Goldberg R, et al. Assessing ozone-related health impacts under a changing climate. Environ Health Perspect. 2004;112:1557-63.

[102] Physick W, Cope M, Lee S. The impact of climate change on ozone-related mortality in Sydney. International journal of environmental research and public health. 2014;11:1034-48.

[103] Sheffield PE, Knowlton K, Carr JL, Kinney PL. Modeling of regional climate change effects on ground-level ozone and childhood asthma. Am J Prev Med. 2011;41:251-7; quiz A3.

[104] Tagaris E, Liao K-J, DeLucia AJ, Deck L, Amar P, Russell AG. Potential impact of climate change on air pollution-related human health effects. Environmental science \& technology. 2009;43:4979-88.

[105] Department of Energy. The 2010 Building Energy Data Book. Washington , D.C.

http://buildingsdatabook.eren.doe.gov/ChapterIntro1.aspx?1\#4 [accessed December 2014]: .

[106] European Commission. Research and innovation, key enabling technologies.

http://ec.europa.eu/research/industrial_technologies/eeb-challenges-ahead_en.html [Accessed December 2014].

[107] Crump C, Macmillan A, Swainson M. Indoor air qualit in energy efficient homes - a review. United Kingdom: IHS BRE Press; 2009.

[108] Shrubsole C, Macmillan A, Davies M, May N. 100 Unintended consequences of policies to improve the energy efficiency of the UK housing stock. Indoor and Built Environment. 2014:1420326X14524586. 
[109] Davies M, Oreszczyn T. The unintended consequences of decarbonising the built environment: A UK case study. Energy and Buildings. 2012;46:80-5.

[110] Weschler C, Shields HC, Naik DV. Indoor ozone exposures. Journal of the Air Pollution Control Association. 1989;39:1562-8.

[111] Dutton SM, Banks D, Brunswick SL, Fisk WJ. Health and economic implications of natural ventilation in offices. Building and Environment. 2013;67:34-45.

[112] Fisk WJ, Mirer AG, Mendell MJ. Quantitative relationship of sick building syndrome symptoms with ventilation rates. Indoor Air. 2009;19:159-65.

[113] Sundell J, Levin H, Nazaroff WW, Cain WS, Fisk WJ, Grimsrud DT, et al. Ventilation rates and health: multidisciplinary review of the scientific literature. Indoor Air. 2011;21:191-204.

[114] Milner J, Shrubsole C, Das P, Jones B, Ridley I, Chalabi Z, et al. Home energy efficiency and radon related risk of lung cancer: modelling study. BMJ: British Medical Journal. 2014;348.

[115] Arlian LG, Neal JS, Morgan MS, Vyszenski-Moher DL, Rapp CM, Alexander AK. Reducing relative humidity is a practical way to control dust mites and their allergens in homes in temperate climates. J Allergy Clin Immunol. 2001;107:99-104.

[116] Arlian LG, Neal JS, Vyszenski-Moher DL. Reducing relative humidity to control the house dust mite Dermatophagoides farinae. J Allergy Clin Immunol. 1999;104:852-6.

[117] Harving H, Korsgaard J, Dahl R. House-dust mites and associated environmental conditions in Danish homes. Allergy. 1993;48:106-9.

[118] IOM. Clearing the air: asthma and indoor air exposures. Washington, D.C.: Institute of Medicine, National Academy of Sciences, National Academy Press; 2000.

[119] Salthammer T, Fuhrmann F, Kaufhold S, Meyer B, Schwarz A. Effects of climatic parameters on formaldehyde concentrations in indoor air. Indoor Air. 1995;5:120-8.

[120] Hirst E, White D, Goeltz R. Indoor temperature changes in retrofit homes. Energy. 1985;10:861-70.

[121] Chapman R, Howden-Chapman P, Viggers H, O'dea D, Kennedy M. Retrofitting houses with insulation: a cost-benefit analysis of a randomised community trial. Journal of Epidemiology and Community Health. 2009;63:271-7.

[122] Howden-Chapman P, Matheson A, Crane J, Viggers H, Cunningham M, Blakely T, et al. Effect of insulating existing houses on health inequality: cluster randomised study in the community. British Medical Journal. 2007;334:460.

[123] Offermann FJ. Ventilation and indor air quality in new homes, CEC-500-2009-085. Sacramento, CA: California Energy Commission and Californa Environmental Protection Agency; 2009. 